\title{
The validation of HPLC analytical method for Allium hookeri Thwaites and Curcuma longa complex extract as functional ingredients
}

\author{
Eunjin Choi, Kyeo-nyeo Oh, Jiae Hong, Changsik Jeong, Sojeng Im, \\ Cho-een Kim, Seul-gi Lee, Chulyung Choi* \\ Jellanamdo Institute of Natural Resources Research, Jangheung 59338, Korea
}

\section{삼채 - 강황 복합추출물의 기능성 원료 표준화를 위한 HPLC 분석법 검증}

\author{
최은진 · 오교녀 · 홍지애 · 정창식 · 임소정 - 김초인 - 이슬기 · 최철웅* \\ (재)전라남도생물산업진흥원 천연자원연구센터
}

\begin{abstract}
This study was preformed to establish a simple and reliable HPLC/UV analytical method to determine p-coumaric acid contents for the standardization of water extracts of Allium hookeri and Curcuma longa complex as functional health food ingredients. The quantitative HPLC method was optimized using a reversed-phase $\mathrm{C}_{18}$ column at $35^{\circ} \mathrm{C}$ with methanol and $\mathrm{H}_{2} \mathrm{O}(30: 70, \mathrm{v} / \mathrm{v})$ as the gradient mobile phase at a flow rate of $1.0 \mathrm{~mL} / \mathrm{min}$ and along with detection wavelength of UV $300 \mathrm{~nm}$. This HPLC/UV analytical method exhibited good specificity and high linearity in the tested range of $1.0-10.0 \mathrm{mg} / \mathrm{mL}$ with excellent coefficient of determination $\left(R^{2}\right)$ of 1.0 . The limit of detection and limit of quantification were 0.08 and $0.24 \mu \mathrm{g} / \mathrm{mL}$, respectively. In addition, the relative standard deviation values from the intra and inter-day precision measurements were 0.4 and $0.1 \%$, respectively. These results indicate that the established HPLC/UV analytical method is simple, specific, precise, accurate, and reproducible and so could be employed in the quantitative analysis of $p$-coumaric acid as a functional compound in Allium hookeri Thwaites and Curcuma longa complex.
\end{abstract}

Key words : Allium hookeri Thwaites, Curcuma longa, p-coumaric acid, HPLC/UV, validation

서 론

삼채(Allium hookeri Thwaites)는 단맛, 매운맛, 쓴맛의 세가지 독특한 향과 맛이 난다해서 삼채라고 이름 붙여졌 다. 삼채는 히말라야 고산지대의 고산식물로써 주로 미얀 마나 중국, 인도, 티벳 등의 고산지대에서 자생하던 식물 로, 식재료 또는 약초로 이용됐다. 고대 중국인들은 3,000 년 전부터 삼채를 식용 및 약용으로 사용해 왔고, 유럽에서 는 고급식재료로 활용하고 있으며, 우리나라에서는 2010년 이후부터 재배가 시작되었다(Ayam, 2011; You 등, 2013).
현재 삼채 잎과 뿌리 추출물에 대한 항암작용, 혈관질환 예방, 당뇨병 개선, 노화 방지 및 피부질환 개선, 뼈 강화작 용등 이 보고되어 있다(Banerjee, 2002; Kim, 2012a; Kim, 2012b; Welch, 1992). 삼채의 주요 성분으로는 잎과 뿌리 단백질, 당, 섬유소, ascorbic acid, phytosterol, total phenol, methyl sulfonylmethane(MSM) 등이 알려져 있다(Bea, 2012; Borborah, 2014; Lee, 2015). 또한, 울금의 기원식물이라고 할 수 있는 강황(Curcuma longa)은 생강과(Zingiberaceae) 에 속하는 여러해살이 식물로서 남아시아와 동남아시아 에 분포한다. 울금은 식용하는 부위에 따라 울금과 강황으

*Corresponding author. E-mail : blockstar@hanmail.net, Phone : +82-61-860-2620, Fax : +82-61-864-7105

Received 03 February 2020; Revised 04 March 2020; Accepted 17 March 2020.

Copyright (c) The Korean Society of Food Preservation.

This is an Open Access article distributed under the terms of the Creative Commons Attribution Non-Commercial License (http://creativecommons.org/licenses/by-nc/4.0) which permits unrestricted non-commercial use, distribution, and reproduction in any medium, provided the original work is properly cited. 
로 나뉘는데, 울금은 식물의 덩이뿌리를 이용하고, 강황은 식물의 덩이줄기뿌리를 이용한다. 강황의 맛은 울금보다 더 맵고 색은 더 진한 오렌지색을 띈다(Kim, 2005). 강황의 분포지역은 제주도 서귀포와 남해안 일대 등이 있으며, 전남 진도군은 전국 울금 재배 면적의 $70 \%$ 를 차지하는 주산지이다. 강황의 효능 및 효과에는 플라보노이드 성분 이 많이 함유되어 있어 주로 항균활성과 항산화 연구가 많이 보고되었으며, 이 외에도 심혈관질환 예방, 치매 예방, 혈중 콜레스테롤 예방 등 효능도 보고되어 있다(Priyadarsini, 1997; Choi, 2004; Kang, 2007). 강황의 주요성분으로는 curcumin, irucabinole, tumerone, azulene, kaemfperol 등이 있 다(Soh, 1998; Ansar, 2005; FDA, 2012; Seo, 2013).

건강기능식품을 개발 - 생산하기 위해서는 원료의 표준 화와 규격화가 매우 중요한 부분이다. 또한, 천연물의 기능 성 원료 인정을 위해서는 기능성과 안전성, 기준·규격을 과학적 근거 자료로 입증하고, 기능 및 지표성분의 표준화, 기능성 원료에 대한 제조 공정의 표준화 및 기준규격 설정 과 관리가 중요하다. 이러한 천연물 유래 식품 소재의 기능 성과 안전성을 과학적으로 입증하기 위해 지표성분의 함 량을 통한 품질관리법이 유용하게 쓰이고 있으며, 분석방 법의 신뢰성 검증으로 시험법밸리데이션(validation)이 필 요하다. 이에 본 연구에서는 삼채(Allium hookeri Thwaites) $70 \%$ 에탄올추출물과 강황(Curcuma longa) $30 \%$ 에탄올 추출물을 제조하고 이를 7:3 비율로 혼합하여 실험에 사용 하였다. 개별인정형 건강기능식품 기능성 원료를 개발할 목적으로 phenolic compound인 p-coumaric acid(Fig. 1)를 지표성분으로 선정하였으며, 이를 지표물질로 활용하기 위해 표준화된 방법을 통한 $p$-coumaric acid 분석법을 확립 및 유효성을 검증(validation)하여 원료 표준화의 기초자료 로 활용 하고자 하였다(KFDA, 2015).

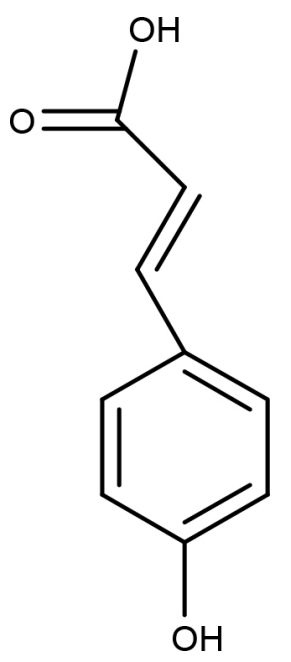

Fig. 1. Molecular structure of $p$-coumaric acid.

\section{재료 및 방법}

\section{삼채·강황 복합추출물 제조}

본 실험에 사용한 삼채(Allium hookeri Thwaites)와 강황 (Curcuma longa)은 삼재영 농조합(Jindo, Korea)과 화순한 약재유통(Hwasun, Korea)에서 구입한 삼채와 강황으로 써, 삼채 $70 \%$ 에탄올 및 강황 $30 \%$ 에탄올 추출 및 동결 건조 후 냉장 $\left(4^{\circ} \mathrm{C}\right)$ 보관된 것을 좋은영농조합법인(Naju, Korea)으로부터 받아 사용하였다. 삼채와 강황 추출물 분 말은 주관기관인 좋은영농조합법인에서 확립한 제조 공 정에 따라 생산된 것으로 $3 \mathrm{lot}$ 추출하였다. 분쇄한 각 시료는 삼채와 강황을 7:3으로 혼합(삼채 - 강황 복합 추 출물)하여 $50 \mathrm{~g}$ 씩 소포장 후 냉장 보관하며 실험에 사용하 였다.

\section{시약 및 분석기기}

$\mathrm{HPLC}$ 분석 및 시료 조제에 사용한 용매 및 이동상 모두 HPLC급으로 J.T Baker(Pillipsburg, NJ, USA)사의 제품을 모두 사용하였다. 또한, PDA 측정을 위해 Waters 2695 HPLC system(Waters, milfod, MA,USA)의 검출기 Waters 2996 photo diode array(DAD)를 사용하였고, 모든 분석 조 건은 천연자원연구센터에서 확립한 조건을 동일하게 사 용하였다.

\section{표준용액 조제}

$p$-Coumaric acid는 Sigma-Aldrich Co.(St. Louis, MO, $\mathrm{USA})$ 의 것을 사용하였다. 추출용매와 표준품 제조 및 이 동상에 사용한 용매는 HPLC급 용매를 사용하였다. 표준 품은 $50 \%$ methanol에 녹여 $1 \mathrm{mg} / \mathrm{mL}$ 가 되도록 표준용액 stock을 제조한 뒤 단계적으로 희석하여 4 농도 $(1,2.5,5$, $10 \mu \mathrm{g} / \mathrm{mL})$ 의 농도별 면적에 따른 검량선을 작성하였다.

\section{시험용액 조제}

삼채 - 강황 복합물의 에탄올 추출 후 여과 및 농축하여 건조한 뒤 얻어진 복합물 $1.0 \mathrm{~g}$ 을 정확히 취하여 volumetric flask에 넣고, HPLC 등급의 $50 \%$ methanol을 가하여 100 $\mathrm{mL}$ 표선을 맞추어 시험 용액으로 하였다. 시험용액은 0.45 $\mu \mathrm{m}$ syringes filter 사용여과 후 검액으로 사용하였다.

\section{$\mathrm{HPLC}$ 분석법 검증}

HPLC 분석법 검증을 위하여 본 실험에서 삼채 - 강황 복합추출물의 건강기능식품 원료 표준화를 위해 지표성 분으로써 $p$-coumaric acid로 정한 후, HPLC를 이용하여 밸리데이션을 실시하였다. 지표성분 분석을 위해서는 분 석법을 설정하는 과정이 필요하기 때문에 설정된 분석법 
이 재현성이 있고 신뢰성이 있는 결과를 얻을 수 있는지 검증과정인 확립된 분석법에 대해 밸리데이션을 실시하 였다(KFDA, 2004; Mertz, 2007).

\section{특이성(Specificity)}

삼채 - 강황 복합추출물의 특이성 실험은 두 소재 복합 추출물이 혼합되어 있는 상태에서 $p$-coumaric acid를 선택 적으로 정확하게 측정할 수 있는 능력을 의미한다. 삼채 강황 복합 추출물에서 $p$-coumaric acid를 선택적으로 측정 할 수 있는 정도를 나타내는 특이성의 검증을 위하여 표준 용액과 시험용액을 HPLC로 분석한 뒤, 크로마토그램을 비 교하여 표준물질의 peak가 분리되는지를 확인하였고, peak 간 간섭 정도를 측정하였다. 분석에 필요한 blank $(\mathrm{MeOH})$, 표준용액 $(1.0 \mathrm{mg} / \mathrm{mL}$ ), 시험용액(삼채 $70 \% \mathrm{EtOH}$, 강황 $30 \% \mathrm{EtOH}=7: 3$ 복합물, $1.0 \mathrm{~g} / 100 \mathrm{~mL}$ ), 조제된 blank, 표준 용액, 시험용액을 각각 3 회 분석하였다. 이때 $p$-coumaric acid의 주 peak에 간섭이 없음을 확인하였고, 표준액과 시 험용액의 peak 머무름 시간(retention time)이 동일함을 확 인하였다. $p$-Coumaric acid 표준용액과 삼채 - 강황복합 추출물을 HPLC로 분석한 뒤, 크로마토그램상의 머무름 시간(retention time)과 비교하여 $p$-coumaric acid의 peak가 분리되는지 확인하였다. 또한, photo diode array(PDA) spectrum을 측정하여 동한 spectrum을 나타내는지 확인하 였다.

\section{직선성(Linearity) 및 범위}

시험방법이 일정한 범위 내에 있는 $p$-coumaric acid 농도 에 대하여 직선적인 측정값을 얻어낼 수 있는 능력을 의미 하는 직선성을 검증하기 위해 4 개의 농도의 검체를 3 반복 하여 실험을 진행하였고, 분석 후 얻은 값의 피크 면적비 와 농도비의 관계를 알 수 있는 희귀분석을 통하여 표준 검량선을 얻었다. $p$-Coumaric acid 표준품을 $50 \%$ methanol 에 용해시켜 분석에 필요한 각각 다른 농도 범위로 $1,2.5$, $5,10 \mu \mathrm{g} / \mathrm{mL}$ 를 만들었다. 농도별의 표준액을 각 3회씩 HPLC에 주입하여 $p$-coumaric acid 주입 농도와 피크면적 간의 결정계수, 기울기, $\mathrm{y}$ 절편을 구하였다.

\section{정확성(Accuracy)}

측정값을 이미 알고 있는 참값이나 표준값에 근접한 정확도로서 실측치가 참값에 얼마나 가까운가를 의미하 는 정확성을 검증하기 위해 $p$-coumaric $\operatorname{acid}(1 \mathrm{mg} / \mathrm{mL})$ 를 $50 \%$ methanol에 녹여 최종농도가 $1,2.5,5 \mu \mathrm{g} / \mathrm{mL}$ 가 되도록 시험용액을 조제하고, 각각 3 회씩 분석하였다. 직선성에 서 얻은 검량선을 이용하여 각 검액의 실측 농도 값을 구하였고, 실제 첨가된 이론 농도값에 대한 회수율(\%)을 구하여 기준에 적합한지를 확인하였다.

\section{정밀성(Precision)}

동일 실험자가 동일한 조작 조건하에서 균일한 검체를 짧은 시간차로 반복분석 실험하여 얻은 측정값들 사이의 근접성을 의미하는 반복성 실험을 진행하였다. 또한, 표준 용액과 동일한 농도로 조제한 시료를 분석하여 검량선을 작성한 다음, 시험용액에 $p$-coumaric acid 표준원액을 spiking 처리하여 최종 농도 $1.0 \mathrm{mg} / \mathrm{mL}$ 로 만든 후 시험용 액을 분석하였으며, 전 조작을 6 회 반복 시험하여 반복성 (repeatability)과 실험실내 정밀성(intermediate precision)을 확인하였다. 시험을 통해 6회 측정한 농도 값 간의 평균, 표준편차, 상대표준편차(relative standard deviation, $\mathrm{RSD} \%$ ) 를 구하였다.

\section{검출한계(LOD) 및 정량한계(LOQ)}

직선성의 검증을 통해 얻은 검량선의 기울기와 표준편 차를 통해 검출한계 및 정량 한계를 구하였다. $p$-Coumaric acid의 검출한계(limited of detection, LOD)는 시료에 포함 되는 지표성분의 검출이 가능한 최소량 또는 최저 농도, 정량한계(limited of quantification, LOQ)는 시료에 포함되 어 있는 지표성분의 정량이 가능한 최소량 또는 최저 농도 로써 $\mathrm{LOD}$ 와 $\mathrm{LOQ}$ 는 반응의 표준편차와 검량선의 기울기 에 근거하여 산출하였다.

$$
\begin{aligned}
& \mathrm{LOD}=3.3 \times(\mathrm{SD} / \text { Slope of calibration curve }) \\
& \mathrm{LOQ}=10 \times(\mathrm{SD} / \text { Slope of calibration curve }) \\
& \mathrm{SD}: \text { standard deviation of the response }
\end{aligned}
$$

\section{삼채 - 강황 복합 추출물의 P-coumaric acid 함량 분석}

진도산 삼채 - 강황 복합 추출물에 함유된 지표성분인 $p$-coumaric acid 함량을 분석하기 위해 $1.0 \mathrm{~g} / 100 \mathrm{~mL}$ 농도 의 시료를 3회 반복 분석하였으며, 표준용액의 크로마토 그램의 피크 면적을 통하여 작성된 검량선에 의해 삼채 강황 복합 추출물 시료 중 함유된 $p$-coumaric acid 함량을 산출하였다.

\section{결과 및 고찰}

\section{분석조건 확립}

삼채 - 강황 복합 추출물의 지표성분인 $p$-coumaric acid (Fig. 1)에 대해 분석을 실시하기 위해 column, 이동상의 종류 및 $\mathrm{UV}$ 검출 파장을 최적화하여 분석을 진행하였으 며, 그 결과는 Table 1과 같다.

\section{특이성 확인}

표준용액과 조제된 삼채 · 강황 복합 추출물 시험용액 에 크로마토그램을 비교하여 함유된 표준물질의 피크가 
Table1. Analytical conditions of HPLC for p-coumaric acid in Allium hookeri Thwaites $70 \%$ ethanol extract and Curcuma longa $30 \%$ ethanol extract complex

\begin{tabular}{cc}
\hline Parameters & Condition \\
\hline HPLC system & Waters 2695 \\
Column & $\begin{array}{c}\text { Agilent } \text { ZORABX Eclipse XDB- } \mathrm{C}_{18} \\
(5 \mu \mathrm{m}, 4.6 \times 250 \mathrm{~mm}, \text { Santa Clara, CA, } \\
\text { USA })\end{array}$ \\
Detector & UV $300 \mathrm{~nm}$ \\
Flow rate & $1.0 \mathrm{~mL} / \mathrm{min}$ \\
Column temperature & $35^{\circ} \mathrm{C}$ \\
Injection volume & $10 \mu \mathrm{L}$ \\
Mobile phase & Methanol: $\mathrm{H}_{2} \mathrm{O}(0.1 \%$ formic acid $)=30: 70$ \\
\hline
\end{tabular}

분리되는지를 확인한 결과, 다른 물질 간섭 없이 단일한 피크로 분리되었으며, 표준용액의 피크유지시간과 시험 용액의 피크 유지 시간 또한 일치하였다(Fig. 2). 표준용액 과 시험용액의 PDA spectrum을 측정한 결과에서도 226.1 - $309 \mathrm{~nm}$ 에서 동일한 spectrum을 나타내어, 본 시험법의 특이성을 확인하였다.

\section{직선성 및 범위}

각 농도별로 단계적으로 조제한 표준용액을 HPLC로 분석하여 피크 면적비에 대한 농도비의 관계를 표시하는 표준검량선을 작성하였다. 측정한 $1-10 \mu \mathrm{g} / \mathrm{mL}$ 의 농도범 위에서 3 회 분석하여 적성한 검량선의 결정계수 $\left(\mathrm{R}^{2}\right)$ 는 0.9999 이상의 높은 직선성을 보였다(Fig. 3).

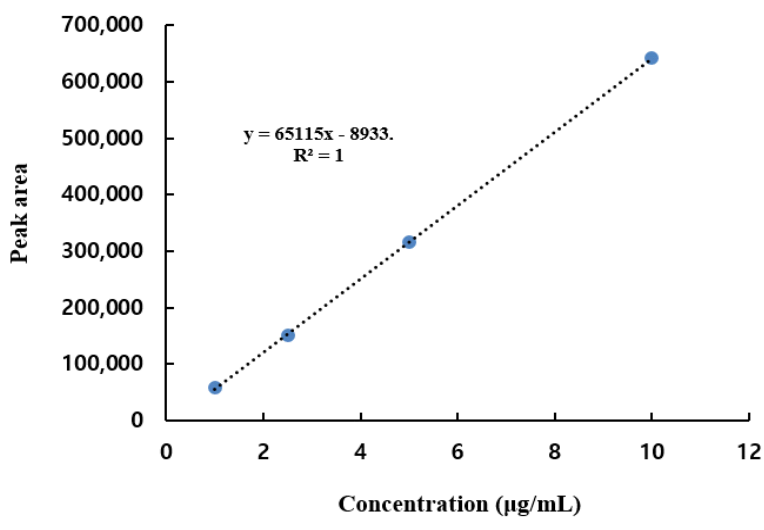

Fig. 3. Calibration curve of p-coumaric acid standard solution.

\section{정확성}

지표성분을 농도별로 시험용액을 조제하여 각 3회씩 분석한 결과, Table 2에 나타난 바와 같이 표준물질의 회수 율은 $1 \mu \mathrm{g} / \mathrm{mL}$ 의 농도에서 $97.74 \pm 0.009,2.5 \mu \mathrm{g} / \mathrm{mL}$ 의 농도 에서는 $99.71 \pm 0.007$, 그리고 $5 \mu \mathrm{g} / \mathrm{mL}$ 에서는 $101.02 \pm 0.024$ 의 범위의 높은 회수율을 보였으며, 분석오차 $0.013 \%$ 를 나타내었다.

\section{정밀성}

반복성(repeatability)과 실험실 내 정밀성(intermediate precision)으로 실험하였으며, 정밀도(RSD)를 측정한 결과 는 Table 3 과 같다. 반복성 시험에서는 $1.0 \mathrm{mg} / \mathrm{mL}$ 의 농도 로 조제한 시험용액을 6 회 반복하여 분석한 측정값이 평 균 $106.8 \pm 0.4 \%$ 를 나타내었고, 실험실 내 정밀성의 1 차 시 험에서 $1.0 \mathrm{mg} / \mathrm{mL}$ 의 농도로 조제한 시험용액의 측정값이
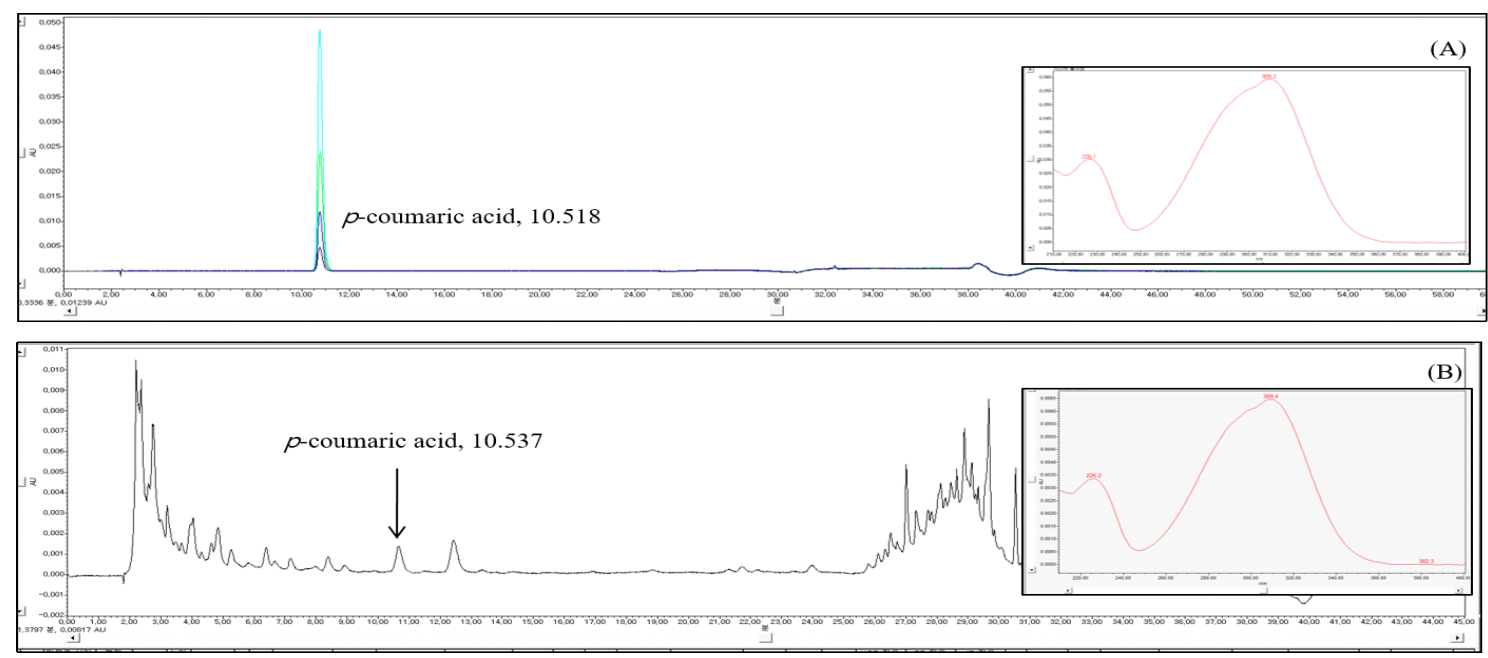

Fig. 2. The HPLC chromatograms of $p$-coumaric acid $(1,2.5,5,10 \mu \mathrm{g} / \mathrm{mL})$ standards and spectrophotometer spectrum of $p$-coumaric acid (A). Allium hookeri Thwaites 70\% ethanol extract and Curcuma longa 30\% ethanolextract complex (1.0 g/100 mL), Allium hookeri Thwaites $70 \%$ ethanol extract and Curcuma longa $30 \%$ ethanol extract complex (B). 
Table 2. Recoveries and relative standard deviations of $p$-coumaric acid in HPLC analysis for validation

\begin{tabular}{cccc}
\hline $\begin{array}{c}\text { Concentration } \\
(\mu \mathrm{g} / \mathrm{mL})\end{array}$ & $\begin{array}{c}\text { Recovery } \\
(\%)\end{array}$ & Mean $\pm \mathrm{SD}^{1)}$ & RSD $(\%)^{2)}$ \\
\hline 5 & 100.4 & & \\
& 101.3 & $101.02 \pm 0.024$ & 0.486 \\
& 101.2 & & \\
2.5 & 100.0 & $99.40 \pm 0.007$ & 0.297 \\
& 99.7 & & \\
& 99.4 & & \\
\hline & 98.6 & $97.74 \pm 0.009$ & 1.000 \\
& 96.7 & & \\
\hline
\end{tabular}

${ }^{1)}$ Each values was the mean $\pm \mathrm{SD}(\mathrm{n}=3)$.

${ }^{2)}$ Relative standard deviation.
평균 $105.9 \pm 0.3 \%, 2$ 차로 측정 값은 $105.8 \pm 0.2 \%$ 를 나타냄으 로써 1 차 시험과 2 차 시험간의 $\mathrm{RSD} 0.2 \%$ 로 적합함을 확인 하였다.

\section{정량한계 및 검출한계}

직선성 검증을 통해 얻은 검량선의 기울기와 표준편차 (y 절편)를 통해 검출한계를 구한 결과, 검출한계는 0.082 $\mu \mathrm{g} / \mathrm{mL}$, 정량한계는 $0.249 \mu \mathrm{g} / \mathrm{mL}$ 수준으로 나타났다. 이는 삼채 - 강황 복합 추출물 시료에 적용할 경우, 지표성분 $p$-coumaric acid의 함량이 약 $2.3 \%$ 수준으로 함유하는 것 을 확인할 수 있었다(Table 4).

\section{삼채·강황 복합 추출물 중 $p$-coumaric acid 함량 분석}

삼채 · 강황 복합 추출물에 함유된 $p$-coumaric acid 함량 을 분석하기 전 강황 $30 \%$ 에탄올 추출물 단독으로 지표성 분 확인 결과, $113.4 \mathrm{mg} / 100 \mathrm{~g}$ 함유하는 것을 확인하였다. 이 위 결과를 바탕으로 복합물 시료를 $1.0 \mathrm{~g}$ 을 정밀하게

Table 3. Precision data of analytical method for p-coumaric acid in Allium hookeri Thwaites $70 \%$ ethanol extract and Curcuma longa $30 \%$ ethanol extract complex

\begin{tabular}{|c|c|c|c|c|}
\hline Precision & Concentration & Recovery (\%) & Mean $\pm \mathrm{SD}^{1)}$ & $\operatorname{RSD}(\%)^{2)}$ \\
\hline \multirow{6}{*}{ Repeatability } & \multirow{6}{*}{1.0} & 106.2 & \multirow{6}{*}{$106.8 \pm 0.4$} & \multirow{6}{*}{0.4} \\
\hline & & 106.9 & & \\
\hline & & 106.6 & & \\
\hline & & 107.3 & & \\
\hline & & 106.8 & & \\
\hline & & 106.8 & & \\
\hline \multirow{12}{*}{$\begin{array}{l}\text { Intermediate } \\
\text { precision }\end{array}$} & \multirow{6}{*}{1.0} & 106.4 & \multirow{6}{*}{$105.9 \pm 0.3$} & \multirow{6}{*}{0.3} \\
\hline & & 105.9 & & \\
\hline & & 105.3 & & \\
\hline & & 106.2 & & \\
\hline & & 105.6 & & \\
\hline & & 105.9 & & \\
\hline & \multirow{6}{*}{1.0} & 105.4 & \multirow{6}{*}{$105.8 \pm 0.2$} & \multirow{6}{*}{0.1} \\
\hline & & 105.8 & & \\
\hline & & 105.7 & & \\
\hline & & 106.1 & & \\
\hline & & 105.9 & & \\
\hline & & 105.7 & & \\
\hline
\end{tabular}

${ }^{1)}$ Each values was the mean \pm SD $(n=3)$.

${ }^{2}$ Relative standard deviation. 
Table 4. The linearity, correlation coefficient $\left(\mathbf{R}^{2}\right)$, limit of detection (LOD) and limit of quantification (LOQ)

\begin{tabular}{cccccc}
\hline Compound & Linear range $(\mu \mathrm{g} / \mathrm{mL})$ & Regression equation ${ }^{1)}$ & $\mathrm{R}^{2}(\mathrm{n}=4)$ & $\mathrm{LOD}(\mu \mathrm{g} / \mathrm{mL})$ & $\mathrm{LOQ}(\mu \mathrm{g} / \mathrm{mL})$ \\
\hline$p$-Coumaric acid & $1-10$ & $\mathrm{y}=65115 \mathrm{x}-8933$ & 1 & 0.082 & 0.249 \\
\hline
\end{tabular}

${ }^{1)} \mathrm{y}$, peak area; $\mathrm{x}$, concentration $(\mu \mathrm{g} / \mathrm{mL})$.

취하여 $50 \%$ 메탄올에 녹여 $100 \mathrm{~mL}$ 조제한 용액을 3 회 반복하여 분석하였을 때, 복합물 중 $2.3 \pm 0.09 \%(\mathrm{RSD} 3.8 \%)$ 의 $p$-coumaric acid가 함유되어 있음을 확인하였다. 이상의 분석결과, 본 연구의 기기분석법과 유효성검증을 통해 삼 채 - 강황 복합추출물의 지표성분인 $p$-coumaric acid의 정 량분석하는데 있어 추가적인 기기의 설비 없이도 일반적 인 검출기인 $\mathrm{HPLC/UV}$ 법을 적용하여 간편하게 $p$-coumaric acid를 정량할 수 있는 분석 방법을 개발하여 그 타당성을 검증하였다. 따라서 이러한 결과를 토대로 건강기능식품 기능성 원료로서 삼채-강황 복합추출물의 지표성분인 $p$-coumaric acid의 분석이 가능함을 확인하였다.

\section{요 약}

삼채 - 강황복합 추출물 골관절개선 건강기능식품 개발 을 위해 선행연구로 air pouch arthritis 동물모델 및 adjuvant rhtumatoid arthritis 동물모델을 이용하여 삼채와 강황 복합 추출물 비율별 $(3: 7,5: 5,7: 3)$ 골관절 개선 효능을 검색한 결과, 삼채 - 강황 7:3 비율의 복합 추출물에서 골관절 개선 효능이 있는 것을 확인하였다(data not shown). 위 결과를 바탕으로 삼채 - 강황 7:3 비율의 복합 추출물 원료의 표준 화를 위한 $p$-coumaric acid 함량 및 분석법 검증을 실시하 였다. 분석법 검증결과, HPLC를 이용한 분석방법에서 표 준용액의 피크 유지 시간과 삼채·강황의 7:3 복합 추출물 의 피크 유지 시간이 일치하였으며, 동일한 spectrum을 나타내는 것으로 특이성을 확인하였다. $p$-Coumaric acid의 검량선은 각각 $1.0,0.999,0.999$ 로 1 에 가까운 높은 직선성 을 보여주어 분석에 적합함을 알 수 있었다. $p$-coumaric acid 의 검출한계(LOD)는 $0.082 \mu \mathrm{g} / \mathrm{mL}$ 이었고, 정 량한계(LOQ) 는 $0.249 \mu \mathrm{g} / \mathrm{mL}$ 로 설정되었다. 정확성에서는 $97.74 \pm 0.009$ $101.02 \pm 0.024$ 로 높은 수준의 $p$-coumaric acid 회수율을 보 였으며, 평균분석오차 $0.013 \%$ 로서 기순인 $10 \%$ 이내를 만 족하였다. 또한, 반복성에서는 평균 $106.8 \pm 0.4$ 로 RSD $0.4 \%$ 를 나타내었고, 실험실 내 정밀성에서 RSD $0.2 \%$, 완 건성에서는 RSD 4.8, 0.3, 3.6\%를 나타내는 것을 확인하였 다. 한편, 삼채- 강황 복합 추출물 중에는 지표성분인 $p$-coumaric acid가 $2.3 \pm 0.09 \%(\mathrm{RSD} 3.8 \%$ ) 함유되어 있는 것 으로 확인되었다. 이상의 실험결과, 삼채 - 강황 복합 추출 물의 골관절개선 건강기능식품 지표성분인 $p$-coumaric acid의 HPLC-UV 분석방법은 특이성, 직선성, 정확성, 정
밀성, 반복성, 완건성 등의 모든 항목에서 validation 기준 에 적합한 시험 방법으로 확인되었다.

\section{감사의 글}

본 연구는 중소벤처기업부 지역주력산업육성 기술개 발사업(P0003114)으로 수행된 연구결과입니다. 그리고 삼 채 - 강황 복합추출물을 제공한 좋은영농조합법인에 감사 드립니다.

\section{Conflict of interests}

The authors declare no potential conflict of interest.

\section{ORCID}

Chulyung Choi https://orcid.org/0000-0003-2006-635X

\section{References}

Ansari MJ, Ahmad S, Kohli K, Ali J, Khar RK. Stabilityindicating HPTLC determination of curcumin in bulk drug andpharmaceutical formulations. J Pharm Biomed Anal, 39, 132-138 (2005)

Ayam VS. Allium hookeri, Thw. Enum. alesser known terrestrial perennial herb used as food and its ethnobotanical relevance in Manipur. Afr J Food Agric Nutr Dev, 11, 5389-5412 (2011)

Bae GC, Bae DY. The anti-inflammatory effects of ethanol extract of Allium hookeri cultivated in South Korea. Kor J Herbology, 6, 55-61 (2012)

Banerjee Sk, Maulik SK. Effect of garlic on cardiovascular disorders: a review. Nutr J, 1, 1-14 (2002)

Borborah K, Dutta B, Borthakur SK. Traditional uses of Allium L. species from North east India with special reference to their pharmacological activities. Am J Phytomed Clin Ther, 8, 1037-1051 (2014)

Choi SK. Growth characteristics of Curcuma longa L. in southern part of Korea. Korean J Medicinal Crop Sci, $12,85-88$ (2004) 
Kang SK. Changes in organic acid, mineral, color, curcumin and bitter substance of Curcuma longa L. and Curcuma atomatica Salib according to picking time. Korean J Food Preserv, 14, 633-638 (2007)

KFDA. Analytical Method Guideline about Validation of Drugs and Etc. Korea Food and Drug Administration, Korea, p 1-18 (2004)

KFDA. Guideline for Standard of Health Functional Food. Korea Food and Drug Administration, Korea, p 6-13 (2007)

Kim CH, Lee MA, Kim TW, Jang JY, Kim HJ. Antiinflammatory effect of Allium hookeri root methanol extract in LPS-induced RAW264.7 cells. J Korean Soc Food Sci Nutr, 41, 1645-1648 (2012a)

Kim KH, Kim HJ, Byun MW, Yook HS. Antioxidant and antimicrobial activities of ethanol extract from six vegetables containing different sulfer compounds. J Korean Soc Food Sci Nutr, 41, 577-583 (2012b)

Kim SB. Old food culture of South Korea. Garamplanning, p 286 (2006)

Lee YR. Physiological activities of ethanol extracts from different parts of Allium hookeri. Korean J Food Nutr, 28, 295-301 (2015)

Merts C, Cheynier V, Gunata Z, Brat P. Analysis of phenolic compounds in two blackberry species (Rubus glaucus and Rubus adenotrichus) by high-performance liquid chromatography with diode array detection and electrospray ion trap mass sprectrometry. J Agric Food Chem, 55, 8616$8624(2007)$

MFDS. http://www.foodsafetykorea.go.kr/foodcode/01_02.js p?idx $=263$, Ministry of Food and Drug Safety (accessed Dec 2019)

Priyadarsini KI. Free radical reactions of curcumin in membrance models. Free Radical Biol Med, 23, 838-843 (1997)

Seo JS. Quality characteristics of a dumpling shell with Curcuma longa L. powder added. Korean J Food Preserv, 20, 621-627 (2013)

Soh HO. A study on the stability and dyeing condition in the Curcuma longa L.. J Korean Soc Costume, 39, 79-89 (1998)

Welch C, Wuarin L, Sidell N. Antiproliferative effect of the garlic compound $S$-allyl cysteine on human neuroblastoma cells in vitro. Cancer Lett, 63, 211-219 (1992)

You BR, Kim E, Jang JY, Choi HJ, Kim HJ. Qulity characteristics of kimchi with Allium hookeri root powder added. Korean J Food Preserv, 20, 863-870 (2013) 